\title{
Developing Children's Leadership Qualities in Public Institutions: a Theoretical Approach
}

\author{
Liliya Ibragimova \\ Faculty of Pedagogy and Psychology \\ Nizhnevartovsk State University \\ Lenin str. 56, 628605 Nizhnevartovsk \\ Russian Federation \\ e-mail: laibra@yandex.ru \\ Nadezhda Zhmakina \\ Faculty of Pedagogy and Psychology \\ Nizhnevartovsk State University \\ Lenin str. 56, 628605 Nizhnevartovsk \\ Russian Federation \\ e-mail: zm-nadya@mail.ru
}

\begin{abstract}
The paper presents the theoretical foundations for studying the development of children's leadership qualities in a child 's public institution. Today, the issue of developing the personality of a child as a full-fledged citizen capable of fulfilling his/her personal and civilian capabilities and positively expressing himself /herself in society is becoming more topical. This problem can be exemplified by the growing number of public institutions with a positive impact on the personal development of children and teenagers. Guided by professional and experienced teachers, children and teenagers are engaged in socially useful activities. The paper considers the main Russian studies devoted to activities in children's public institutions, including those on the issues of their history, organization and functioning. Researchers have paid much interest to the educational functions of children's institutions, to the training of teachers working with children in children's public institutions, to the socializing of teenagers in such institutions, and to the educational impact of children's public institutions on the social engagement of teenagers. The authors consider a children's public institution as a space for social education and analyse the studies that represent potential of children 's organizations as means of the social engagement of children and teenagers. Modern research sources and the realities of the educational and sociocultural situation show the growing interest to the issues of personality development, education and social adaptation. After analysing the pedagogical studies and summarizing the experience of several educational institutions, the authors conclude that by developing the leadership qualities in teenagers when performing activities in a children's public institution, one promotes personal self-actualization and develops personal readiness to make life choices.
\end{abstract}

\section{Introduction}

The modern Russian society finds it as a particularly important task to help children develop their characters and become fully-fledged citizens who are able to realise their personal potential and opportunities within a society, citizens who are able to be of positive influence. Many public institutions that demonstrate solid growth and development throughout our vast and multinational country undertake this task. It is worth mentioning there are public institutions, which do promote healthy personality development for their children and teenagers. Guided by professional educators these children and adolescents are engaged in good community activities. This task has been presented for study in the academic sphere, as well as in the field of personality development in children in public institutions.

Democratisation of the Russian society and our entering the market-based economic system demand us now to prepare citizens, who can meet challenges, be initiative and responsible for their actions. Transformations in Russia are leading to the fact that one of the most important aspects in personality development has become social engagement.

Now when the government has less participation in meeting basic needs of its nation, now when a person is entirely responsible for their life, it seems evident that only an active individual, who can perform with success in all life spheres, may take responsibility for his/her own future and the future of his/her country. Modern ways of forming civil society should aim at self-actualization for individuals and communities. Maintaining civil society cannot be achieved only by political measures. Overcoming indifference and encouraging creativity in every citizen are now the main challenge in development of the modern Russian society.

The set objective required scientific thinking, experience in social education and defining the nature and 
principles of effective interaction of theory and practice.

Childcare, as in public organized activities for children, carries a great social and educational potential. Public institutions for children are the most organized and reliable segments within the childcare field as they serve educational purposes. Within the framework of the research the works that were dedicated to functioning of public institutions for children present a special significance.

Several Russian scholars have dedicated their works to the matters of history and management of public institutions for children. A great deal of attention has been paid to educational functions in such public institutions for children (Taran 2000; Kovrov 1996), training an adult to work with children in public institutions (Kirpichnik 1995; Kulpedinova 1996; Rutkovskaya 1994), socialization of a teenager in public institutions (Volokhov 1996), public institutions as a way to produce educational impact on teenagers' social engagement.

Viewing public institutions as a space for social education, we have analysed those works that represent public institutions as centres of social activities for children and youth.

Analyses of the scientific literature and reviews of the modern educational and socio-cultural situation prove an increased focus in educational sphere on personality development, character formation and social adaptation.

However, despite the sharp focus on the mentioned issues, comprehensive investigations upon developing leadership qualities in public institutions for children still seem necessary in this field.

Our literature review of the subject and analysis of the problem in several general education institutions allow us to state the following: developing leadership qualities in teenagers of children's public institutions appears to be the way to achieve self-actualization of an individual and help adolescents learn to make good decisions. Giving all children the opportunity to feel themselves true members of society with rights and duties, engaging them in subject-to-subject relations and various social activities in order to promote personality development and self-actualization, practicing various social roles with children - all this allows us to rank public institutions as a unique educational space for developing leadership qualities in adolescents.

\section{Theoretical account of leadership formation: a literature review}

A leader is a man of action, who stands out for his/her wit, initiative, lively character, communicativeness, competitiveness, the one who aspires to self-actualization.

There are several approaches to the concept of leadership in modern psychology and education. These approaches may significantly differ in the matter of how leadership emerges. As leadership theories have been developed in Western and Russian psychologies rather independently, it seems reasonable to study the main approaches in isolation from each other.

We can single out the following widely acknowledged theories -the theory of trait leadership, the situational leadership theory, and the situational-personal leadership. The first half of the $20^{\text {th }}$ century shows that it was the theory of trait leadership that gained great prominence. It emerged as a consequence of the research works by an English psychologist and anthropologist, Galton, who at the end of the $19^{\text {th }}$ century was already trying to prove that leadership traits were heritable and could not be developed.

The theory of trait leadership is also known as the Charismatic leadership theory. The name derives from the Greek word charisma which means "gift of grace" and which in various religions is interpreted as something that is bestowed upon a man. The theory can also be traced back to ideas of German psychology in the late $19^{\text {th }}$ and early $20^{\text {th }}$ centuries, as it focused primarily on finding heritable leadership traits.

The trait theory suggests it is specific personality traits that contribute to leaders' success. The theory proclaims heritability and excellence of a leader's traits. Thus, leadership being a social and psychological phenomenon should be studied as synergy of traits that give leaders an opportunity to stand out, take the lead and hold power.

According to the theory of trait leadership, not every individual can become a leader but rather one must be born a leader. The theory followers such as Bogardus, Baird consider intelligence, strong will, ambition, organizational skills, competence to be distinctive qualities of a leader.

As it has already been mentioned, many scholars have endeavoured to define leaders' traits or characteristics. However, it turned out to be hardly possible to compile a precise list of personality traits.

Extensive research was conducted to justify the trait theory. And it created doubts about the theory's core concept since a detailed analysis of leadership traits showed that they fully matched the set of psychological and social attributes of an individual in general.

Despite the plausible argument, it did not mean complete rejection of the trait theory. It is evident that in order to attain a leading position a person must possess certain psychological and social characteristics. However, a list of such traits may considerably change depending on historical periods, this or that country and this or that situation.

Andrienko (2002) points out that the trait theory has received considerable criticism because different functions of a social group require different leadership traits. 
Ashin's statements come rather in line with our research. Ashin (1978) believes the trait theory lacks one important point -performing leader's functions either develops or encourages leadership qualities. If a man has performed the role over a long period of time, he/she interiorizes the proper functions and this way acquires necessary personality traits for leader effectiveness.

Leadership apparently has a more complex nature and it depends not only on personality traits but also on an individual's situation and their position in intergroup relations. Close observations and practice demonstrate that the one, who has a clear understanding of problems and solutions, who shows a greater performance than other members within a group, becomes the leader.

Further scientific work revealed that it was impossible to create a universal list of leadership traits and that a set of certain traits does not necessarily make this or that person a leader. This criticism led to the trait theory's decline in popularity. Subsequently, a new theory-Situational Leadership Model-emerged and took the place of the trait leadership theory. The situational theory's followers are Bales, Newcomb, Hare, or Pigors.

According to the theory, leadership is a product of a situation within a group. If a person becomes a leader in one group, he/she acquires a reputation that starts to work for them.

Thus, such a person can be viewed as a leader in general. Various life situations may require this or that quality and the person, who appears to have superior qualities required for the situation, becomes the leader in that group.

Therefore, many scientists discarded the theory of leadership heritability and welcomed the concept that a leader is a person who better exercises this or that quality in a particular situation and that the quality may reside in others as well. Traits and qualities of a leader turned out to be rather relative (Andreeva 2001).

The situational theory emerged around fifty years ago and it easily edged out the trait theory that was dominant back then. However, as we see - it undermines an individual's proactivity and ranks a set of conditions as the driving force that entirely determines a leader's behaviour. The theory supporters underrate a leader's selfsufficiency and his/her ability to influence events.

Nevertheless, the situational leadership theory appeared to be widely accepted. Based on the theory, there has been a great number of experimental leadership researches conducted within the system of group dynamics.

In the 1950s, the leadership research focus started to shift into the research field of group relations. Subsequently, it gave place to a new complex, systemic theory, which integrate the ideas of both -the trait theory and the situational theory. The scholars who supported it were Krachfield, Homans, Krech.

The Systems Theory of Leadership followers believe leadership is a process of managing interpersonal relations where a leader is the managing subject. This means leadership is viewed in the context of organizing and performing work within a group. The approach implies that leadership may be interpreted as a group function. Therefore, it should be studied from the perspective of a group's goals and tasks but including a leader's personal traits (Petrovsky 1980).

Interactive Leadership Model presents a different approach and concepts. In his work Theory of Activity Mediation and Leadership Problem Petrovsky (1980) mentions that the interactive leadership theorists claim anyone can become a leader. It is conditioned not as much by his/her own personality characteristics but rather by synergy of a potential leader's traits plus other group members' traits plus a group's structure. The model authors have been developing the idea that it is possible to predict who may take the leading role. And to be able to predict it we need to take into account a potential leader's traits, other members' traits and a group's structure in the given situation.

As we can see, leadership interpretation, understanding its principles have considerably transformed and evolved in the western literature. However, these days there is still no uniform understanding of the notion leadership. Every researcher attempting to define it accentuates only this or that aspect.

\section{Leadership and management}

The Russian psychology studies the leadership concept applying such terms as activist, director, organizer. Umansky (2004) in his thesis says that effectiveness of analysis of modern terms in correlation to their theories was studied by Matskevich and introduced as the principle of rational modernization. The author proclaims "the point is not that we should not look at the past through the lens of modern thinking. Rather, we should not ascribe nowadays issues to the past, i.e. the problem resides in reflexiveness of historical and research thinking and methods" (Umansky 2004).

In our opinion, Zherebova (1973) aptly approaches leadership covering many of its aspects. The theorist regards leadership not only as one of the keys to successful organizations and management but also studies it in the context of group activity from the leader's role perspective, where the leader is not just 'given' the role, but where he/she 'takes' the role due to his/her personality traits and skills.

There is a rather interesting view on leadership presented by Dubovskaya who has studied the phenomenon applying the notion interinfluence. Dubovskaya (1984) believes that leadership is interinfluence between the leader and group members, who depend on each other while achieving the same goals in group situations. Leadership in 
her work is determined by such factors as leader's characteristics, followers' characteristics, and group situation's characteristics.

Volkov approaches leadership from a different angle. The author studies leadership through such notions as organization and management. According to Volkov (1997), leadership is a process of inner social and psychological organization and management of communication and functioning of group members conducted by a leader as a subject of group principles and values spontaneously formed in interpersonal relations. There is hence a need to analyse leadership taking into account leader's individual characteristics, group principles and values, the character of group functioning and the importance of a situation.

A very comprehensive interpretation for leadership was proposed by Parygin (1971). The scholar examines leadership in the context of social management is a small group (team) and thinks there are two factors which determine leadership:

1) objective factor (interests, goals, needs, tasks of a group in one situation);

2) subjective factor (personality traits of an individual who organizes and initiated group activity).

In this matter his vision overlaps with those of Volkov and Dubovskaya.

Based on his own research results, Parygin (1971) has come to certain conclusions:

- a leader is not chosen by a group, but rather spontaneously takes the leading role with explicit or implicit consent of a group;

- when choosing a leader, members off-the-record create a set of group values based on leader's personality and they identify themselves with it;

- choosing a leader is always predetermined by an important situation for group's functioning.

Another interesting view of leadership is presented by Krichevsky (1991), who proposed to analyse leadership taking into account structure characteristics, enablers, and dynamics patterns. According to the author, the leading role does not necessarily imply that it is always the leader who initiates organizing something. In this sense, leadership potential is comprised of emotional, moral or professional only characteristics of a leader.

In our opinion, Karpov's understanding of leadership includes some aspects of behavioural approach. The theorist states leader's behaviour can be acquired by any member of a group and some members succeed in one activity, while the others perform better in another.

According to Karpov (1999), the mechanism of role assignment is determined by situational leadership in the process of decision-making. It means that at different stages of decision-making different group members may take the lead, more frequently those ones whose type and personality satisfy the situation needs at this or that stage. Thus, for example, at the very beginning of the decision-making, when the situation is least clear, it is an 'intellectual', who takes on leading, but then it can be taken by a 'critic', and so on.

In our opinion, Umansky (2004) gives a rather full and deep interpretation of leadership. The scholar views leadership as a social and psychological phenomenon, which is reasoned by one leading influence upon other group members in order to propose the best solution for group's problem.

Leadership is a form of social activity within a group. A leading person always demonstrates a pro-active approach to life and has influence on other group members (Zherebova 1973).

As we can see, the theoretical account shows how much effort scholars have put in to define leadership. Attempting to define it many of them focus on different aspects of leadership, which, as a result, brings us to a pool of definitions. They highlight important characteristics of the notion, as in leading role in achieving group's goals and a leader being a part of informal structure of relations. Leader's effectiveness is considered to be determined by group's success.

If we quickly to analyse the word 'lider' (in Russian), then we need to mention its English origin and its literal meaning - 'leading'.

Zherebova interprets leadership from the perspective of leader's actions. According to the theorist, a leader is a group member who is chosen as a result of members interaction and who - under the condition his values match the group's values- then manages this group around himself and organizes it in order to achieve group's goals. A leader is someone who leads a group, plans and manages group tasks, showing this way higher activity than other group members (Zherebova 1973).

It is also worth mentioning Rozhkov and his views. The author sees a leader as a person who is able lead, motivate to perform a task, influence the ones around. Rozhkov categorizes leaders into 'creators' and 'destroyers'. The difference lies in their orientation, viz. a creator/leader acts for the benefit of a project, organization and all its members, while a destroyer/leader pursues his/her own interests. For a destroyer it is not the common goal and people that are of importance, but rather a desire to show himself/herself (Rozhkov and Volokhov 1996).

Petrovsky (1980) see a leader as a member who is entitled to make serious decisions in important situations for a group. It is the most influential person who indeed acts the central role in organizing group activities and managing group relations. 
In our opinion, Umansky (2004) presents a rather comprehensive interpretation of leadership revealing the main signs that enable us to define a leader:

- the first sign is group membership, i.e. a leader is a member of a group, he/she is inside a group and not beyond or above;

- the second sign is a status in a group, i.e. a leader is treated with respect and has a privileged status;

- the third sign is common value-based orientations, i.e. there are common values in a group and a leader is best to present group's interests;

- the fourth sign is leader's power over a group, i.e. a leader is able to influence behaviour and minds of other group members, organize and manage a group to achieve group goals;

- the fifth sign is the source of leadership in a group (Udaltsova 2001).

Having analysed the theories about leadership and leader, we can see that in the Russian literature there is leadership viewed as a social and psychological concept (Volkov 1997; Zherebova 1973), there is leadership viewed as relations of dominance and subordination in the processes of organizing and managing a group (Umansky 2004; Dubovskaya 1984; Parygin 1971). Additionally, leadership can only appear within a social group.

Leadership is a social and psychological phenomenon that occurs in dynamic activities of a small group and its main point is to create leading influence over other members and produce the best decision-making.

The Russian scholars view a leader as the centre of a group, the subject that manages interpersonal relations inside a group and its organizer. A leader cannot function solo, he/she always functions as an element of a group structure, which is why leader's effectiveness is perceived as an ability to positively influence a group in order to best solve a common problem acute for one whole group.

Taking into account statements by Krichevsky (1991), Karpov (1999), we suppose that leader's behaviour can be acquired by any group member with some members succeeding in one activity and others showing better results in the other. In the present research we view a leader in a children's public institution as a group member with better results in a particular task, a member whom a group gives the rights to make serious decisions in important situations. It is the most powerful person who plays the central role in this or that activity.

Furthermore, the correlation between leadership and actual management presents yet another very important aspect of leadership. Here it seems most important to, first of all, distinguish the terms leader and manager.

Some researchers consider these terms as synonyms. They provide proof that one cannot become a leader not being an effective manager in the first place, and vice versa. Other researchers make a clear distinction between the terms. For them management is a set of actions based on pre-trained techniques and tools, whereas leadership remains a mystery based on personality and that appears in processes of influence and power. According to Mintzberg (1989), leadership is one of the roles of a manager. According to Zaleznik (1993), leaders and managers differ in their personality traits, goal orientation, interaction with others, views about work and self-perception.

The research work Sociology of Management by Udaltsova (2001) is of a great value. The author aptly points out that any group is conditioned by the matters of leadership and management to one extent or another. Since any organization includes formal and informal relationships among its members, it is reasonable to distinguish formal and informal leaders.

The theories review shows that many researchers studying the terms leader and manager do it in the context of general leadership theories where a leader and a manager are considered to be a person with power over a group and a leader appears to be a part of informal relations, while a manager is presented in formal relations.

From the social and psychological perspective, leadership and management are mechanisms of group integration that unite group actions around one individual who performs as a leader and manager (Vezhevich 2001). The two concepts have a lot in common. Udaltsova (2001) singles out the following common features:

- both are types of building, coordinating relations inside an organization via management;

- both implement social influence inside a group;

- both imply relations of subordination

As for distinctions between the two, scholars (Parygin 1971; Krichevsky 1991) name the following:

- leadership is mainly about managing group's personal, i.e. informal relations, whereas management is about managing formal, professional relations.

- leadership is mainly presented in a micro group, whereas management is an element of a macro group with its system of social relations.

- leadership emerges and functions spontaneously, whereas management process means planning and controlling in social organizations and institutions.

- unlike leadership management is more stable and there is less probability for opinion and mood changes among group members.

- management exercises a certain system of sanctions more than leadership.

- unlike leadership decision-making in management is more complicated and decisions may be revised multiple times (Krichevsky 1991). 
Volkov (1997) shares similar views about management and leadership. According to the author management is a process of managing legal matters and group members in common activities, where a manager is a representative of social control and power. Leadership is a process of social and psychological organization, it is about managing communication and activities of a small group, where a leader is a subject of group values spontaneously formed in interpersonal relations.

Some scholars comment that distinctions between leadership and management are rather relative, since both are interrelated (Krichevsky 1991; Volkov 1997; Andreeva 2001). This often means a manager may be a leader at the same time and a leader under certain conditions may become a manager.

Thus, we may conclude that every group member with his/her professional and personal characteristics has a certain place in the system of group organization. From this perspective, a group's structure is a sort of hierarchy of prestige and status among group members. A leader being at the top of hierarchy gets the right to make most important decisions.

It is clearly evident that leadership is a group phenomenon and all leaders are unique. In this regard, scholars differentiate various types of leaders.

Bales puts forward two leader types, i.e. the task-leader and the social-emotional leader. The task leader proposes new ideas and encourages a group to achieve set goals. The task leader realizes his/her leadership in defining a problem, finding information, in assessing group work and results. The social-emotional leader is concerned with personal and social needs of group members. His/her main task is to maintain group harmony, so he/she does his/her best to create a friendly and trust-worthy atmosphere (Kvinn 2000).

Goleman (2004) provides a very detailed description of leader types. The author proposes six leadership styles (the coaching leader, the visionary leader, the affiliative leader, the democratic leader, the pacesetting leader, the coercive leader) and describes how and which style is best used. However, Goleman approaches leadership using the concept of emotional intelligence, which implies a set of qualities such as self-awareness, abilities to listen to other people and understand, predict their behaviour, control own and others' emotions, make right decisions, as well as abilities to influence and motivate a team to achieve goals. That is why in his analysis of leadership styles the author pays special attention to their impact on group atmosphere (Umansky 2001).

As our theoretical account shows, there are several classifying approaches to different types of leaders presented in the Russian psychology.

For instance, Zherebova (1973) classifies leaders according to interpersonal relations and assignment of duties in a group. Therefore, the theorist proposes such leaders as the leader who finds best ways to achieve a goal, the leader who defines best technical solutions, the leader who creates group atmosphere, the leader who maintains group atmosphere. Umansky (2001) proposes a functional classification of leaders:

- leader-organizer (group integration);

- leader-initiator (sets the pace for group's problem-solving);

- leader-generator of emotional states;

- leader-intellectual;

- leader of emotional appeal (“sociometric star");

- leader-artisan (an expert in his/her field).

Parygin's typology of leadership presented in the book Foundations of Social and Psychological Theories is of great scientific interest. The researcher differentiates leaders on the following grounds:

1. According to work content, there is a leader-programmer who not only creates a situation but also is able to resolve it, and there is a leader-performer who is very sensitive to group moods and replaces a leaderprogrammer only after a situation is created.

2. According to management style, there is an authoritarian leader who is self-oriented and a democratic leader who is group oriented.

3. According to work types, there is a situational leader who can create and settle only particular situations and there is a universal leader who is able to manage various situations.

Developing Umansky's ideas, Chernyshov put forward two types -leaders-organizers and leadersdisorganizers (Shaballas 2002).

Krichevsky in his work (1991) proposes two types of group activity, i.e. instrumental and expressive. Thus, there are instrumental and expressive leaders accordingly. Both types of group activity are connected with group management.

Thus, we may conclude there are many factors for comparing and classifying leaders and, as a result, there are many leadership classifications. We assume that a great number of leader types can be explained by a great number of problems being solved. 
The investigation of leaders' classifications is by no means exhaustive. It is important to understand that even the most thorough theoretical review cannot cover the whole nature of this very complex and multi-sided concept of leadership. Reality is always richer than theory and most frequently creates mixed types of leaders.

In the late 1930s Lewin identified leadership style as a process of influencing other people's behaviour in which a leader uses techniques and tools in order to influence a person or a group (Kvinn 2000). Lewin discovered three different styles of leadership:

- democratic. In the democratic style, the leader involves group members in decision-making. The style is effective in less structured situations. It is oriented at personal relations and creative brainstorming. The leader tends to manage a group with the help of its members and give them freedom to act.

- autocratic. In the autocratic style, the leader makes decisions on his/her own. This style is most effective in well-coordinated situations with lack of time for problem-solving. The leader gives orders and a group follows them.

- laissez-faire. The laissez-faire style allows group members to act as they feel like it, so their activity appears to be very spontaneous. The leader here acts mainly as a coordinator.

A group may have either absolute or limited freedom to act. A leader performs only as an authorized representative of this group while interacting with other groups but within the group he/she possesses less authority.

In most recent research works, along with the above-mentioned styles, there have appeared new terms such as directive leader, liberal leader, collegial leader.

Goleman in his book Primal Leadership (2004) also explores leadership styles. Goleman assumes that there are six leadership styles, each with its positive and negative aspects, and specific situations in which one should use them. The author states that the most effective and successful leaders skilfully apply one or more styles and can switch from one to another when necessary.

Four of the styles (the coaching leadership, the visionary leadership, the affiliative leadership, the democratic leadership) create good group response and, thus, show better performance. The other two (the pacesetting leader, the coercive leader) are rarely used in very specific situations and should be applied with caution.

In Russian social psychology there are three traditionally accepted types of leadership, viz. authoritarian style, democratic style, and liber style.

Recently, however, the traditional classification has been extended and five new styles were proposed, viz. distant style, contact style, goal-setting style, delegating style and problem-managing style. According to the author, each style characterizes leader's personality and his/her managing skills. Also, a point made to pay special attention to leader's ability to switch from one style to another as it is seen as a key factor for successful management of a group and group atmosphere (Krichevsky 1991).

A thorough investigation was conducted by Zhuravlev and Rubakhin (Krichevsky 1991). The scholars propose a wide range of leadership styles: directive style, collegial style, liberal style, directive-collegial style, directive-liberal style, collegial-liberal style and mixed style. Based on empirical data, the researchers name collegial and mixed leaderships most effective from the point of view of group' efficiency and group's psychological climate (Krichevsky 1991).

All in all, leadership is still being researched and refined in modern literature. Avdeev (2018), for instance, not only studies leadership approaches but is developing his own structural model of leader's influence, in which proper leadership means that an ideal leader should well exercise three techniques: sympathy, dominance, and goal setting. And it is not just being able to exercise the three features but rather realizing in which situation one should use this or that technique.

\section{Conclusions}

The theory review shows that although theorists use different terms when defining leadership styles, the overall psychological patterns of the very styles remain distinct and consistent.

The paper strived to give a comparative analysis of the main leadership theories and spotlight the main issues in the Western and Russian literatures. We see that leadership theories have been developed in Western and Russian psychologies rather independently, which led to different leadership approaches.

Thus, our philosophical, social and psychological reviews of the leadership development in children in public institutions make it contextually justified to propose the following methodological principles:

- leadership qualities are a set of qualities and traits that allow a child in a public institution gain more status by performing some activity better than other members and make decisions important for the group;

- $\quad$ public institutions form a unique educational space, as children happen to define themselves, make life choices, integrate and apply social and personal experience more frequently and intensively in 
the environment of public institutions;

- children's public institutions are establishments that develop educational process (and the system of a public institution itself) and increase educational capacity.

Furthermore, the proposed principles seem to imply development of learning and cognitive activity in children (Pogrebnaya e al. 2019) and leadership qualities respectively.

Nowadays leadership researches are acquiring new trends due to social and economic changes in the Russian society and throughout the world. All in all, the modern scientific situation can be characterized by an increasing number of leadership investigations, emergence of new concepts, development of age, gender and ethnic-based leaderships, which all seem as solid foundations for development of cognitive activities in learners.

\section{References}

Andreeva GM, Socialnaya psikhologiya: Uchebnik dlya vysshikh uchebnykh zavedeniy, $5^{\text {th }}$ edn. (Aspekt: Moscow, Russia, 2001), 416 p.

Andrienko EV, Socialnaya psikhologiya: Uchebnik dlya vysshikh ucebnykh zavedeniy, $2^{\text {nd }}$ edn.(Akademiya: Moscow, Russia, 2002), 264 p.

Ashin GK, Kritika sovremennykh burzhuaznykh koncepciy liderstva, $1^{\text {st }}$ edn. (Mysl: Moscow, 1978), 135 p.

Avdeev PS, Psikhologiya liderstva. Ot teorii k praktike, $1^{\text {st }}$ edn. (Izdatelskiye resheniya: Yekateringburg, Russia, 2018), $440 \mathrm{p}$.

Dubovskaya EM (1984) Vliyaniye lidera na sverstnikov v yunosheskykh gruppah. Dissertaciya kand. psih. Nauk. Moscow: $63 \mathrm{p}$.

Goleman D, Primal Leadership, $1^{\text {st }}$ edn. (Harvard Business Review: Brighton, U.S, 2004), 411 p.

Karpov AV, Psikhologiya menedzhmenta, $1^{\text {st }}$ edn. (Gardariki: Moscow, Russia, 1999), 546 p.

Kirpichnik A (1995) Komu I zachem nuzhno detskoye dvizheniye? Teoriya, istoriya, metodika detskogo dvizheniya. Informacionny bulleten 1: 22-24.

Kovrov VA, Lebedev DN, Kulpedinova ME (1996) «Ja» stanovitsa bogache. Teoriya, istoriya, metodika detskogo dvizheniya (TIM). Informacionny bulleten 1:50.

Krichevsky RL, Psikhologiya maloy gruppy, $1^{\text {st }}$ edn. (MSU: Moscow, Russia, 1991), 203 p.

Kvinn V, Prikladnaya Psikhologiya, $1^{\text {st }}$ edn. (Piter: Saint Petersburg, Russia, 2000), 560 p.

Matskevich V, Polemicheskiye etyudy ob obrazovanii, $1^{\text {st }}$ edn. (Pedagogika: Moscow, Russia, 1993), 312 p.

Mintzberg A, Mintzberg on Management: Inside Our Strange World of Organizations, $1^{\text {st }}$ edn. (Collier Macmillan: London, UK, 1989), 418 p.

Parygin BD, Osnovy socialno-psikhologicheskoy teorii, $1^{\text {st }}$ edn. (Mysl: Moscow, USSR, 1971), 351 p.

Petrovsky AV (1980) Teoriya deyatelnostnogo oposredovaniya I problema liderstva. Voprosy psikhologii 2: 2941.

Pogrebnaya LA, Mikhailova SV, Ibragimova LA (2019) Formation of Readiness and Motivation of Students for Independent Work in Higher Technical Educational Institution. Amazonia investiga 8 (21): 483-490.

Rozhkov MI, Volokhov AV, Detskiye organizacii: vozmoznosti vybora. Variativno-programmny podhod k socializacii rebenka $\mathrm{v}$ deyatelnosti detskikh organizaciy: Metodicheskoye posobiye dlya organizatorov detskogo dvizheniya, $1^{\text {st }}$ edn. (Moscow, 1996), $111 \mathrm{p}$.

Rutkovskaya EL, Detskoye dvizheniye: poisk resheniya problem, $1^{\text {st }}$ edn. (M: Moscow, 1994), 95 p.

Shaballas AE (2002) Shkola kak obrazovatelnaya sreda v polikulturnom prostranstve Stavropolskogo kraya. Laboratoriya problem formirovaniya sovremennoy lichnosti v polikulturnoy srede 1: 3-10.

Taran UN, Kak razrabotat programmu detskogo obyedineniya. Metodicheskiye rekomendacii $\mathrm{v}$ voprosah I otvetakh (Lipetsk: 2000), 64 p.

Udaltsova MV, Sociologiya upravleniya, $1^{\text {st }}$ edn. (INFRA-M: Novosibirsk, Russia, 2001), pp. 20-21. 
Umansky LI (2004) Pedagogicheskoye soprovozhdeniye detskogo liderstva: Dissertaciya doktora ped. KGU imeni NA Nekrasova, Kostroma: 321 p.

Umansky LI, Lichnost. Organizatorskaya deyatelnost, $1^{\text {st }}$ edn. (KGU imeni NA Nekrasova: Kostroma, Russia 2001), $208 \mathrm{p}$.

Vezhevich TE (2001) Pedagogicheskiye usloviya razvitiya liderskykh kachestv uchaschihsya: Dis.kand. ped. Nauk. Ulan-Ude: p.198

Volkov IP (1997) K voprosu о metodaлh оcenky organizatorskykh sposobnostey. Vestnik LGU. Ekonomika. Filosofiya. Pravo 23:26.

Zaleznik A, Learning Leadership: Cases and Commentaries on Abuses of Power in Organizations, $1^{\text {st }}$ edn. (Bonus Books: Chicago, U.S, 1993), 540 p.

Zherebova PS, Liderstvo v malykh gruppakh kak obyekt socialno-psikhologicheskogo issledovaniya. Rukovodstvo I liderstvo, $1^{\text {st }}$ edn. (LGPI: Leningrad, 1973), 143 p. 